\title{
40. MIOCENE AND PLIOCENE OXYGEN AND CARBON ISOTOPIC CHANGES AT DSDP SITES 372, 374, AND 375: IMPLICATIONS FOR PRE-MESSINIAN HISTORY OF THE MEDITERRANEAN
}

\author{
C. Vergnaud Grazzini, Laboratoire de Géologie Dynamique, Université Pierre et Marie Curie, Paris, France
}

\begin{abstract}
Oxygen and carbon isotopic analyses of Globigerinoides and mixed benthic species from 34 samples at Site 372 , covering an interval from the lower Miocene (middle Burdigalian, Zone N5/6) to the upper Miocene (pre-Messinian epoch) indicate that the isotopic composition of the Mediterranean waters was already different from the mondial mean (according to the evaluations made by Shackleton and Kennett, 1975 a,b); the hydrologic balance of the Mediterranean might have corresponded to a significantly modified evaporation-precipitation pattern. An average increase of $0.9 \%$ in the $\delta_{\text {water }}$ when passing from the lower Miocene to the upper Serravallian might be interpreted either in terms of glacially induced isotopic changes on a worldwide scale, or as a consequence of minor salinity crises occurring well before the major crisis of the Messinian; the latter seems to have induced a strong increase of more than $3 \%$ in the oxygen isotopic composition of planktonic foraminifera; such increase also correlates with the major advance of the Antarctic ice cap at about -6 m.y. Most probably, salinity crises, superimposed on the general evolution of the mean ocean $\delta$ induced the particular evolution of the oxygen isotopic composition of Mediterranean waters during the middle and late Miocene.

Oxygen and carbon isotopic analyses of Globigerinoides obliquus from the G. margaritae Zone in the Lower Pliocene from Sites 374 and 375 are compared with analyses on the same levels from Site 134 (DSDP Leg 13); they show that there was a difference of about $1 \%$ between the isotopic composition of the waters of the eastern and western basins and that the eastern basin was the more diluted.
\end{abstract}

\section{INTRODUCTION}

The stable isotope analyses on foraminifera from Leg 42A, Sites 372, 374, and 375 (Table 1 and Figure 1) contribute to an understanding of the climatic events which preceded and led to the transformation of the Tethys Ocean into the Mediterranean Sea. The investigations of Benson (1972 a,b; 1974), Benson and Ruggieri (1974), and Benson and Sylvester-Bradley (1971) on the late Neogene ostracode fauna of the Mediterranean Basin seem to prove that during the middle and late Miocene, there was a progressive warming of the bottom waters of the Mediterranean Sea, culminating in the "Lago-mare" of the Messinian "salinity crisis." If such a warming actually occurred it should be reflected in the ${ }^{18} \mathrm{O} /{ }^{16} \mathrm{O}$ ratios of benthic foraminifera tests.

During the same period (upper Miocene) the accumulation of ice on the Antarctic continent changed the average isotopic composition of the oceans by about 0.9 per mil (Shackleton and Kennett, 1975 a,b); these authors suggest that this value should be used as a standard for paleotemperature estimation prior to the accumulation of the Antarctic ice sheet. There is some evidence in the Miocene fauna and flora from the Mediterranean area that the temperatures were higher than at present; thus, a realistic evaluation of Miocene paleotemperatures in the sea should lead to values somewhat higher than present. With this in mind, the validity of the value of $-0.9 \%$ proposed by Shackleton and Kennett can be tested for the waters of the Miocene Mediterranean.

TABLE 1

Locations of the Sites Studied

\begin{tabular}{cccc}
\hline Site & Latitude & Longitude & $\begin{array}{c}\text { Water Depth } \\
(\mathrm{m})\end{array}$ \\
\hline 372 & $40^{\circ} 01.86^{\prime} \mathrm{N}$ & $04^{\circ} 47.79^{\prime} \mathrm{E}$ & 2699 \\
374 & $35^{\circ} 50.87^{\prime} \mathrm{N}$ & $18^{\circ} 11.78^{\prime} \mathrm{E}$ & 4078 \\
375 & $34^{\circ} 45.74^{\prime} \mathrm{N}$ & $31^{\circ} 45.58^{\prime} \mathrm{E}$ & 2101 \\
134 & $39^{\circ} 11.70^{\prime} \mathrm{N}$ & $07^{\circ} 18.25^{\prime} \mathrm{E}$ & 2864 \\
\hline
\end{tabular}




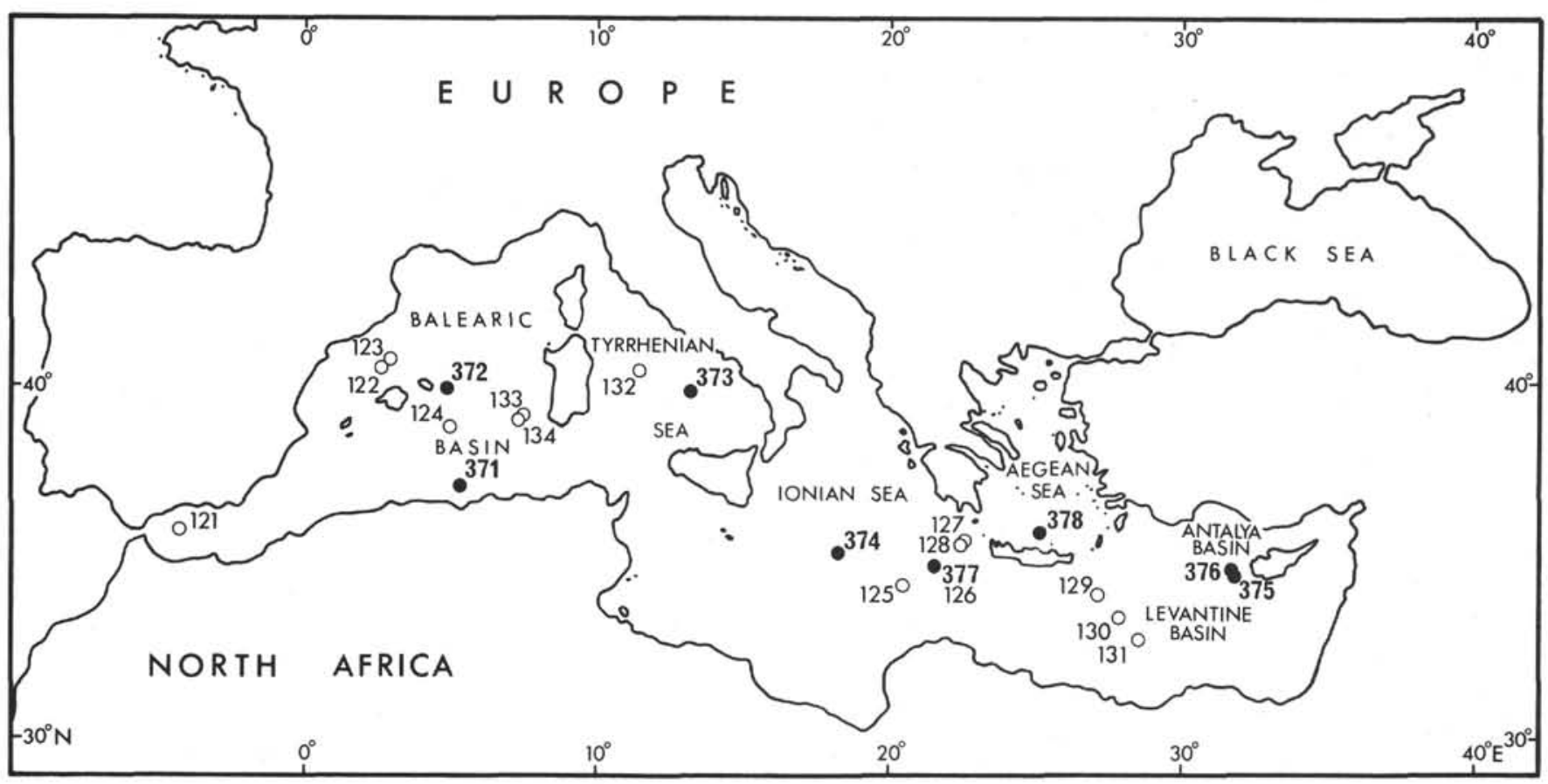

Figure 1. Location of DSDP Leg $42 \mathrm{~A}$ drillsites in relation to those of Leg 13.

\section{ANALYTICAL PROCEDURE}

Samples of both planktonic and benthic foraminifera were extracted from the cores. Monospecific samples of planktonic foraminifera were analyzed, where possible. They were Globigerinoides trilobus, G. subquadratus, and $G$. obliquus. It was not possible to analyze monospecific samples of benthic foraminifera.

The samples consisted of about $0.5 \mathrm{mg}$ of carbonate which were cleaned of organic matter by a 24-hours chlorox treatment; adhering fine-grained matter was removed by ultrasonic cleaning. The carbon dioxide was released by the action of $100 \%$ orthophosphoric acid at $50^{\circ} \mathrm{C}$. Isotope analyses were performed in a VG Micromass mass spectrometer and calibrated by analyzing of standard carbonate samples under identical conditions. Calibration to the PDB standard for both oxygen and carbon isotopes was effected via the NBS 20 standard. The analytical results are given in Tables 2 through 5 and displayed in Figures 2 and 3.

\section{Oxygen Isotope Composition}

The paleotemperature method is based on the fact that, when they are in thermodynamic equilibrium, calcite and seawater differ in their ${ }^{18} \mathrm{O} /{ }^{16} \mathrm{O}$ ratios and that this difference decreases as temperature increases. Shells precipitated in equilibrium with seawater are enriched in ${ }^{18} \mathrm{O}$ relative to seawater, but less so as temperature increases. The relationship between the temperature of precipitation and the isotopic composition is given by an empirical equation of the form:

$$
\mathrm{T}=\mathrm{K}_{1}-\mathrm{K}_{2}\left(\delta-\delta_{\mathrm{w}}\right)+\mathrm{K}_{3}\left(\delta-\delta_{\mathrm{w}}\right)^{2}
$$

where

$$
\delta=\frac{{ }^{18} 0 /{ }^{16} 0_{\text {sample }}-{ }^{18} 0 /{ }^{16} 0_{\text {standard-carbonate }}}{{ }^{18} 0 /{ }^{16} 0_{\text {standard carbonate }}} \times 10^{3}
$$

and

$$
\delta_{\mathrm{w}}=\frac{{ }^{18} 0 /{ }^{16} 0_{\text {water }}-{ }^{18} 0 /{ }^{16} 0_{\text {standard water }}}{{ }^{18} 0 /{ }^{16} 0_{\text {standard water }}} \times 10^{3}
$$

$\mathrm{K}_{1}$ has been determined to be $16.9, \mathrm{~K}_{2}$ is 4.2 , and $\mathrm{K}_{3}$ is 0.13 (Craig, 1965), and $\delta_{\mathrm{w}}$ must be estimated for past geologic time. It is with this estimate, of course, that difficulties arise. As Emiliani (1955) pointed out, there are two factors that change the term $\delta_{\mathrm{w}}$ through time: one is the glacial effect, the other is a change in precipitation-evaporation patterns, referred to as the evaporation effect. The glacial effect consists of a preferential removal of ${ }^{16} \mathrm{O}$ from the ocean during glacial periods, when isotopically light water accumulates on land in the form of ice.

At present, the surface and deep waters of the Mediterranean Sea have an isotopic composition about 1.25 per mil heavier than North Atlantic deep water, as a consequence of greater evaporation (Duplessy, 1972; Vergnaud Grazzini, 1973). As far as the Miocene epoch is concerned, few data are available on a worldwide scale (Devereux, 1967; Douglas and Savin, 1971, 1973; Shackleton and Kennett, 1975a, b). The latter two authors studied samples from DSDP Sites $277,279,281$, and 284 , which are located between the 


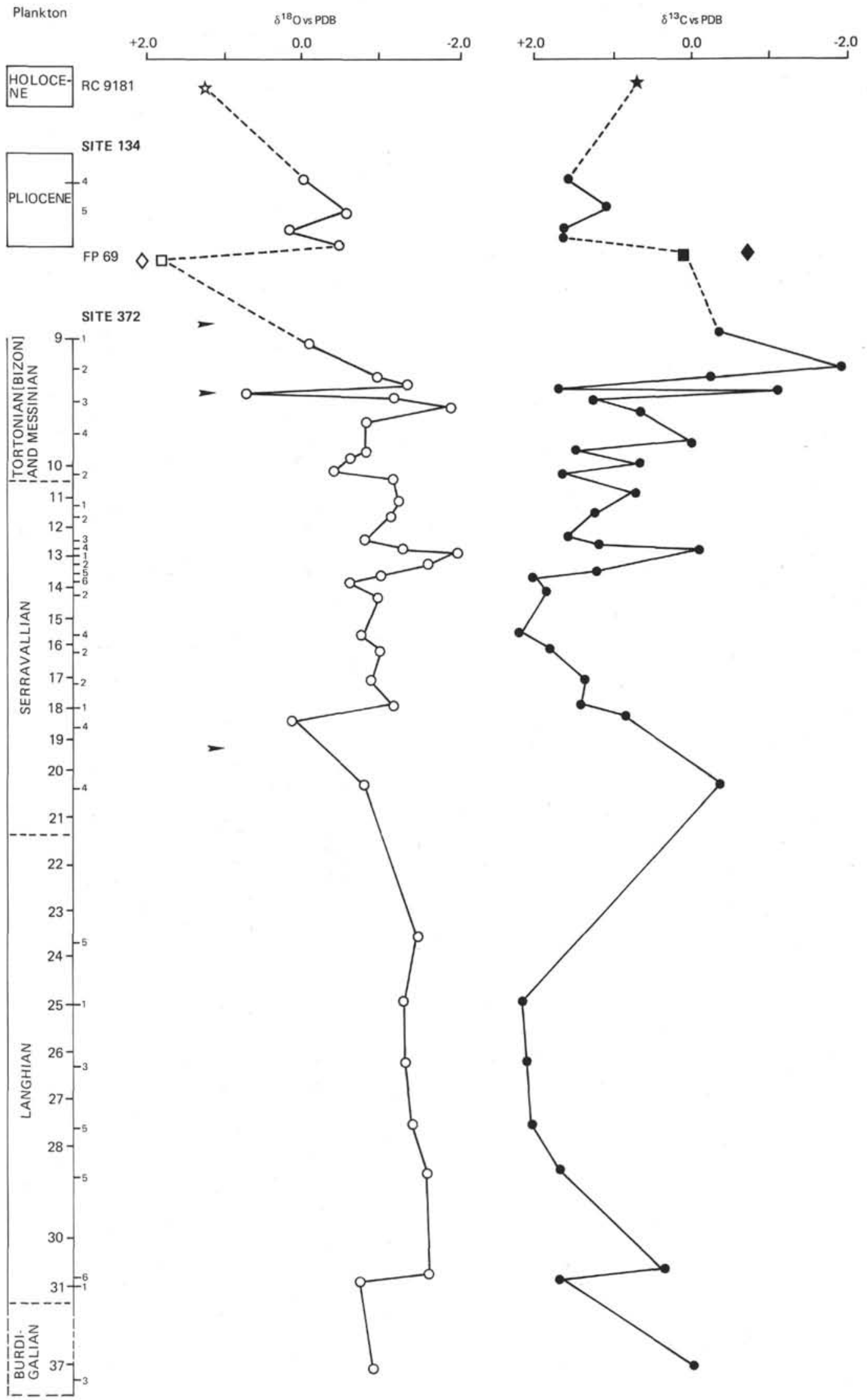

Figure 2. Oxygen and carbon isotopic composition of Globigerinoides and mixed benthic species from Sites 372 and 374 and Recent sediments against their location in the cores. Stratigraphic plot is based on the Serravallian and Langhian stages being nearly equivalent in duration. Either the Tortonian or Messinian is incomplete. 


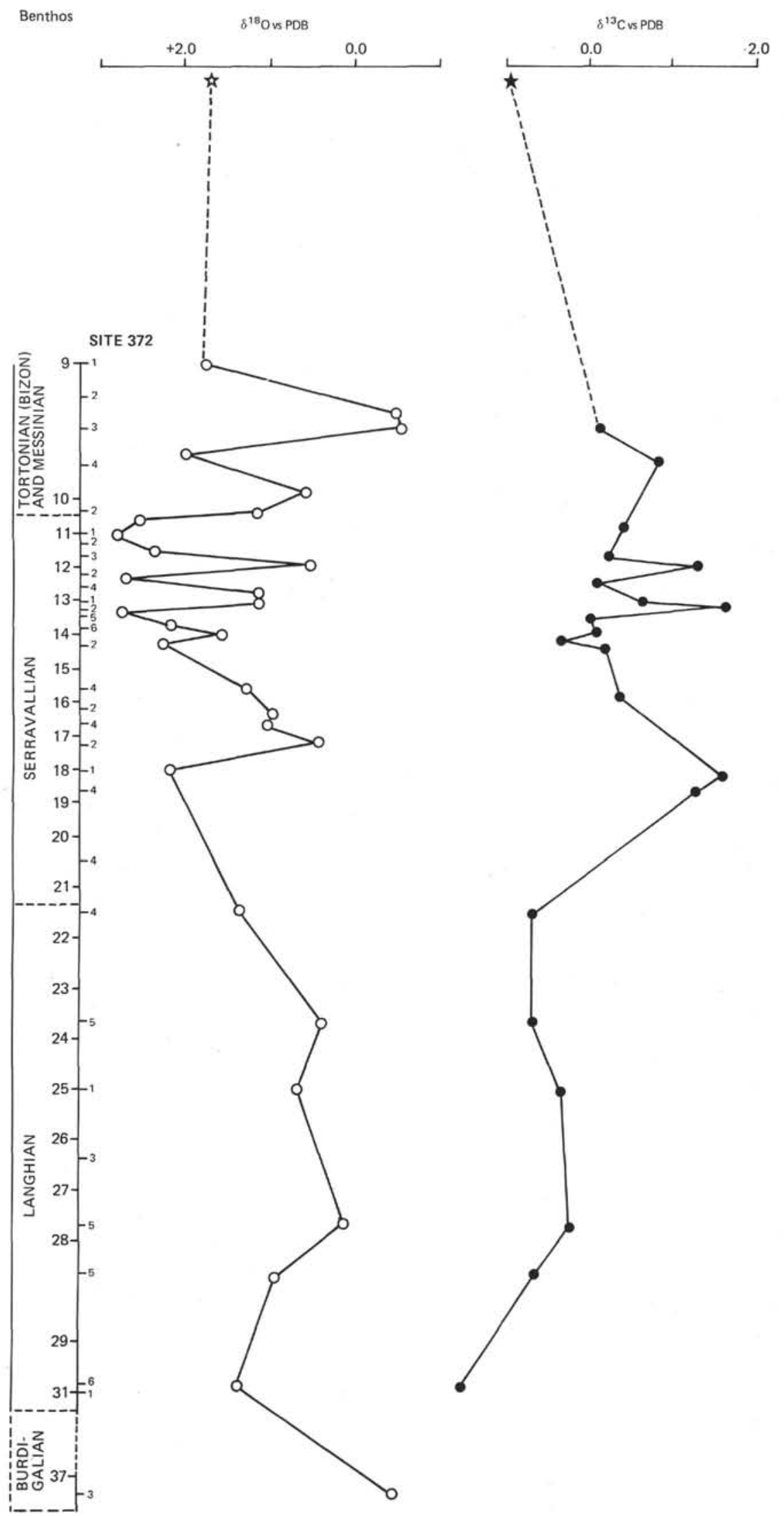

Figure 2. (Continued). 
present subtropical and Antarctic convergence in the Pacific Ocean. They estimated the glacial effect of the accumulation of the Miocene/Antarctic ice sheet and using a value of $-50 \%$ for the isotopic composition of the stored ice, they concluded that the isotopic composition of the ocean, prior to the formation of the present ice sheets, should be -1.2 per mil (expressed in relation to the PDB standard).

The question is, should this value be applied to the Mediterranean basin for the same epoch?

\section{Carbon Isotope Composition}

The factors controlling the isotopic composition of carbon in foraminiferal tests are complex (see Douglas and Savin, 1973): this composition is influenced by, e.g., the temperature of growth of the organisms. This effect is very small though $\left(1^{\circ}\right.$ accounts for $0.03 \%$ ). For the most part, the isotopic composition of carbon is determined by a vital effect which is not precisely understood and by the isotopic composition of dissolved or particulate carbon in the sea (the latter factor is the preponderant one).

\section{RESULTS (Tables 2 through $6^{1}$ )}

\section{Site 372}

Site 372 provided the most complete sampling through the Miocene section. It should be noted, however, that some Messinian samples from this site still have to be analyzed. The results obtained from a core from the same area (FP69) for the pre-Messinian also are reported in Figure 2.

\section{The Lower Miocene}

Up to the early Serravallian stage (below Core 18, Sections 1-4) the oxygen isotopic composition registered by benthic foraminifera varies in a range from $0.0 \%$ to $+1.37 \%$. These values are lower than the ones we measure for different benthic species, living at present in the western Mediterranean, at depths greater than 500 meters. These latter range between $+1.5 \%$ o and $+2.0 \%$ (Vergnaud Grazzini, 1973). The lower range of the former can be explained either in terms of temperature or in terms of $\delta_{\text {water }}$ or both.

During the same period of time, the oxygen isotopic composition of planktonic foraminifera varies between $-0.5 \%$ and $-1.43 \%$; above Core 31 , Section 1 , the composition is rather stable, varying around $-1.2 \%$ 。 Thus, the minimal difference between isotopic compositions registered by planktonic and benthic foraminifera is about twice that observed between the same living forms. Then, on the average, the isotopic compositions of the Miocene foraminifera are significantly lower than those of the Pleistocene period in the same areas.

\footnotetext{
${ }^{1}$ Analyses from some Pliocene levels from Site 134 (DSDP Leg
} 13) are shown in Table 6.
TABLE 2

Oxygen and Carbon Isotope Data for Planktonic Foraminifera at DSDP Site 372a

\begin{tabular}{|c|c|c|c|c|c|c|}
\hline 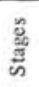 & $\begin{array}{c}\text { Sample } \\
\text { (Interval } \\
\text { in } \mathrm{cm} \text { ) }\end{array}$ & Species & $\delta 18_{0}$ & $\begin{array}{l}\text { Aver- } \\
\text { age } \delta \\
18_{0}\end{array}$ & ${ }_{8}^{113} \mathrm{C}$ & $\begin{array}{l}\text { Aver- } \\
\text { age } 8 \\
{ }^{3} \mathrm{C}\end{array}$ \\
\hline \multirow{2}{*}{ 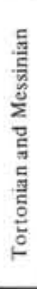 } & $\begin{array}{l}9-1,125 \\
9-2,52 \\
9-2,75 \\
9-2,110 \\
9-2,130\end{array}$ & $\begin{array}{l}\text { Globigerinoides trilobus } \\
\text { Globigerinoides trilobus } \\
\text { Globigerinoides trilobus } \\
\text { Globigerinoides trilobus } \\
\text { Globigerinoides trilobus }\end{array}$ & $\begin{array}{l}+0.03 \\
-0.81 \\
-1.34 \\
+0.79 \\
-1.11\end{array}$ & & $\begin{array}{l}-0.21 \\
-1.80 \\
-0.15 \\
+1.72 \\
-1.03\end{array}$ & -0.29 \\
\hline & $\begin{array}{l}9-3,20 \\
9-3,65 \\
9-4,100 \\
9-4,133 \\
10-2,13 \\
10-2,100\end{array}$ & $\begin{array}{l}\text { Globigerinoides trilobus } \\
\text { Globigerinoides trilobus } \\
\text { Globigerinoides subquadratus } \\
\text { Globigerinoides subquadratus } \\
\text { Globigerinoides subquadratus } \\
\text { Globigerinoides subquadratus }\end{array}$ & $\begin{array}{l}-1.85 \\
-0.74 \\
-0.78 \\
-0.73 \\
-0.27 \\
-1.08\end{array}$ & \multirow[b]{2}{*}{-0.98} & $\begin{array}{l}+1.02 \\
+0.74 \\
+0.02 \\
+1.56 \\
+0.79 \\
+1.74\end{array}$ & \\
\hline \multirow[t]{2}{*}{ 鼠 } & $\begin{array}{l}11-2,130 \\
11-3,130 \\
12-3,20 \\
12-4,120 \\
13-1,120 \\
13-2,130 \\
13-5,100 \\
13-6,100 \\
14-2,20 \\
15-4,120 \\
16-2,120\end{array}$ & $\begin{array}{l}\text { Mixed } G \text {. trilobus }+G \text {. subquadratus } \\
\text { Mixed } G \text {. trilobus }+G \text {, subquadratus } \\
\text { Globigerinoides trilobus } \\
\text { Globigerinoides trilobus } \\
\text { Globigerinoides trilobus } \\
\text { Globigerinoides trilobus } \\
\text { Globigerinoides trilobus } \\
\text { Globigerinoides trilobus } \\
\text { Globigerinoides trilobus } \\
\text { Globigerinoides trilobus } \\
\text { Globigerinoides mixed }\end{array}$ & $\begin{array}{l}-1.17 \\
-1.06 \\
-0.69 \\
-1.20 \\
-1.87 \\
-1.52 \\
-0.88 \\
-0.50 \\
-0.82 \\
-0.63 \\
-0.91\end{array}$ & & $\begin{array}{l}+0.79 \\
+1.28 \\
+1.62 \\
+1.24 \\
-0.02 \\
- \\
+1.35 \\
+2.03 \\
+1.94 \\
+2.31 \\
+1.94\end{array}$ & +1.27 \\
\hline & $\begin{array}{l}17-2,110 \\
18-1,100 \\
18-4,20 \\
20-4,20\end{array}$ & $\begin{array}{l}\text { Globigerinoides trilobus } \\
\text { Globigerinoides trilobus } \\
\text { Globigerinoides trilobus } \\
\text { Globigerinoides trilobus }\end{array}$ & $\begin{array}{l}-0.77 \\
-1.04 \\
+0.30 \\
-0.65\end{array}$ & -0.54 & $\begin{array}{l}+1.42 \\
+1.51 \\
+1.15 \\
-0.33\end{array}$ & +0.93 \\
\hline \multirow[t]{2}{*}{$\begin{array}{l}\text { 맬 } \\
\text { 핼 } \\
\text { 래 }\end{array}$} & $\begin{array}{l}23-5,40 \\
25-1,130 \\
26-3,70 \\
27-5,40 \\
28-5,110 \\
30-6,40 \\
31-1,130\end{array}$ & $\begin{array}{l}\text { Globigerinoides trilobus } \\
\text { Globigerinoides trilobus } \\
\text { Mixed Globigerinoides } \\
\text { Mixed Globigerinoides } \\
\text { Mixed Globigerinoides } \\
\text { Mixed Globigerinoides } \\
\text { Globigerinoides subquadratus }\end{array}$ & $\begin{array}{l}-1.39 \\
-1.16 \\
-1.16 \\
-1.22 \\
-1.43 \\
-1.40 \\
-0.51\end{array}$ & -1.18 & $\begin{array}{l}+ \\
+2.36 \\
+2.32 \\
+2.25 \\
+1.83 \\
+0.54 \\
+1.88\end{array}$ & +1.86 \\
\hline & $37-3,86$ & Mixed Globigerinoides & -0.68 & & +0.06 & \\
\hline
\end{tabular}

aExpressed as deviation per mil from PDB,

\section{Temperatures and $\delta_{\text {water }}$ Estimates}

Assuming that Mediterranean bottom waters of that period were contributed by an ocean with a $\delta$ around $-1.2 \%$ on the PDB scale (Shackleton and Kennett, $1975 \mathrm{a}, \mathrm{b})$, the bottom temperatures would lie between $7^{\circ} \mathrm{C}$ and $12^{\circ} \mathrm{C}$ (average $8.5^{\circ} \mathrm{C}$ ), that is, much lower than present temperatures. As for surface temperatures, one would predict values around $17^{\circ} \mathrm{C}$. These low values, however, for both the bottom and surface temperatures are hardly compatible with the presence of microfaunal assemblages of warm types such as keeled Globorotalia and abundant Globigerinoides. One must conclude that the mean ocean isotopic composition, as evaluated by Shackleton and Kennett represents, at best, an estimate of the minimal $\delta_{\text {water }}$ of the Mediterranean in early Miocene time.

An alternative hypothesis could be that early Miocene Mediterranean bottom waters were produced in a pattern similar to that of today, that is, by sinking of cold, dense, highly saline winter waters (Lacombe and Tchernia, 1971-1972). Assuming that the winter temperatures were not lower than those of the present day (i.e., around $13{ }^{\circ} \mathrm{C}$ ) by using Equation 1 and the $\delta$ values measured for benthic foraminifera, one calculates that the $\delta_{\text {water }}$ might have been higher than $-0.9 \%$ on the PDB scale, with, in some cases, values as high as $+0.5 \%$, and the surface temperatures, based on planktonic $\delta$ values, between $18^{\circ} \mathrm{C}$ and $24^{\circ} \mathrm{C}$. 
TABLE 3

Oxygen and Carbon Isotopic Data for Benthonic Foraminifera at DSDP Site $372^{a}$

\begin{tabular}{|c|c|c|c|c|c|c|}
\hline & $\begin{array}{l}\text { Sample } \\
\text { (Interval } \\
\text { in } \mathrm{cm} \text { ) }\end{array}$ & Species & ${ }_{\delta} 180$ & $\begin{array}{l}\text { Aver- } \\
\text { age } \delta \\
18_{0}\end{array}$ & ${ }^{8} 13 \mathrm{C}$ & $\begin{array}{l}\text { Aver- } \\
\text { age } \delta \\
13 \mathrm{C}\end{array}$ \\
\hline \multirow{2}{*}{ 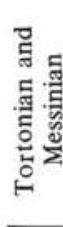 } & $\begin{array}{l}9-1,125 \\
9-2,59 \\
9-2,130\end{array}$ & $\begin{array}{l}\text { Mixed benthics } \\
\text { Mixed benthics } \\
\text { Mixed benthics }\end{array}$ & $\begin{array}{l}+1.71 \\
-0.55 \\
-0.60\end{array}$ & & \multirow{2}{*}{$\begin{array}{c}- \\
- \\
-0.17 \\
-0.92 \\
- \\
+2.57 ? \\
-0.51\end{array}$} & \\
\hline & $\begin{array}{c}9-3,65 \\
9-4,100 \\
10-2,13 \\
10-2,100\end{array}$ & $\begin{array}{l}\text { Mixed benthics } \\
\text { Mixed benthics } \\
\text { Mixed benthics } \\
\text { Mixed benthics }\end{array}$ & $\begin{array}{l}+1.96 \\
+0.55 \\
+1.13 \\
+2.47\end{array}$ & \multirow[b]{2}{*}{+1.63} & & \\
\hline \multirow[t]{2}{*}{ 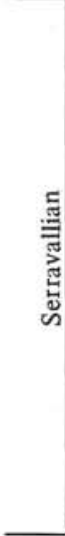 } & $\begin{array}{l}11-1,120 \\
11-2,130 \\
11-3,130 \\
12-3,20 \\
12-4,120 \\
13-1,120 \\
13-2,130 \\
13-3,100 \\
13-5,100 \\
13-6,100 \\
14-2,20 \\
15-4,120 \\
16-2,120 \\
16-4,90\end{array}$ & $\begin{array}{l}\text { Mixed benthics } \\
\text { Mixed benthics } \\
\text { Mixed benthics } \\
\text { Mixed benthics } \\
\text { Mixed benthics } \\
\text { Mixed benthics } \\
\text { Mixed benthics } \\
\text { Mixed benthics } \\
\text { Mixed benthics } \\
\text { Mixed benthics } \\
\text { Mixed benthics } \\
\text { Mixed benthics } \\
\text { Mixed benthics } \\
\text { Mixed benthics }\end{array}$ & $\begin{array}{l}+2.78 \\
+2.31 \\
+0.47 \\
+2.61 \\
+1.04 \\
+1.10 \\
+2.71 \\
+2.09 \\
+1.47 \\
+2.19 \\
+1.15 \\
+0.82 \\
+0.99\end{array}$ & & $\begin{array}{c}- \\
-0.34 \\
-1.31 \\
-0.13 \\
-0.63 \\
-1.73 \\
\\
-0.08 \\
-0.13 \\
+0.21 \\
-0.27 \\
-0.44 \\
- \\
-\end{array}$ & -0.53 \\
\hline & $\begin{array}{l}17-2,110 \\
18-1,100 \\
21-4,140 \\
\end{array}$ & $\begin{array}{l}\text { Mixed benthics } \\
\text { Mixed benthics } \\
\text { Mixed benthics }\end{array}$ & $\begin{array}{l}+0.32 \\
+2.15 \\
+1.24\end{array}$ & & $\begin{array}{l}- \\
-1.77 \\
+0.60 \\
\end{array}$ & \\
\hline 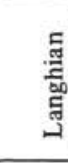 & \begin{tabular}{|l|}
$23-5,40$ \\
$25-1,130$ \\
$27-5,40$ \\
$28-5,110$ \\
$30-6,40$ \\
\end{tabular} & $\begin{array}{l}\text { Mixed benthics } \\
\text { Mixed benthics } \\
\text { Mixed benthics } \\
\text { Mixed benthics } \\
\text { Mixed benthics }\end{array}$ & $\begin{array}{l}+0.27 \\
+0.62 \\
+0.07 \\
+0.87 \\
+1.37\end{array}$ & +0.74 & $\begin{array}{l}+0.58 \\
+0.24 \\
+0.19 \\
+0.59 \\
+1.45\end{array}$ & +0.61 \\
\hline & $37-3,86$ & Mixed benthics & -0.54 & & - & \\
\hline
\end{tabular}

aExpressed as deviation per mil from PDB.

TABLE 4

Oxygen and Carbon Isotopic Data for Planktonic Foraminifera at DSDP Site $374^{a}$

\begin{tabular}{cccc}
\hline $\begin{array}{c}\text { Sample } \\
\text { (Interval in cm) }\end{array}$ & Species & $\delta 18_{0}$ & $\delta{ }^{13} \mathrm{C}$ \\
\hline $9-1,51$ & Globigerinoides obliquus & -0.75 & +0.67 \\
$9-2,33$ & Globigerinoides obliquus & -0.80 & +0.66 \\
$9-3,108$ & Globigerinoides obliquus & -1.04 & +0.81 \\
$10-1,110$ & Globigerinoides obliquus & -1.05 & +0.49 \\
\hline
\end{tabular}

aExpressed as deviation per mil from PDB.

Such estimates are much more compatible with warm microfaunal assemblages.

On the basis of these temperature estimates for early Miocene time, it can be concluded that the isotopic composition of the Mediterranean waters did not reflect the mondial mean, but was the expression of a significantly modified evaporation-precipitation pattern.

\section{The Upper Serravallian and Tortonian Bottom Waters}

From the lower Serravallian up into the lower Tortonian at Site 372 (i.e., up to Section 9, Core 2), the ${ }^{18} \mathrm{O}$ curve for benthic foraminifera can be interpreted
TABLE 5

Oxygen and Carbon Isotope Data for Planktonic Foraminifera at DSDP Site $375^{\mathrm{a}}$

\begin{tabular}{llrl}
\hline $\begin{array}{c}\text { Sample } \\
\text { (Interval } \\
\text { in cm) }\end{array}$ & \multicolumn{1}{c}{ Species } & $\delta 18 \mathrm{O}$ & $\delta 13 \mathrm{C}$ \\
\hline $4-2,73$ & Globigerinoides obliquus & -0.64 & +0.44 \\
$5-1,120$ & Mixed planktonic species & -0.91 & +2.07 \\
$6-1,110$ & Mixed planktonic species & -0.30 & +0.24 \\
$6-2,60$ & Mixed planktonic species & -0.83 & +0.99 \\
$6-3,60$ & Mixed Globigerinoides & -1.23 & +1.14 \\
$6-6,40$ & Mixed Globigerinoides & -1.09 & +0.51 \\
$7-1,120$ & Mixed Globigerinoides & -0.95 & +1.76 \\
$8-2,96$ & Mixed Globigerinoides & -0.67 & +1.38 \\
$9-4,108$ & Mixed recrystallized Globigerinoides & -2.68 & +0.68 \\
$10-3,120$ & Mixed recrystallized Globigerinoides & -2.07 & +1.86 \\
& & & \\
\hline
\end{tabular}

aExpressed as deviation per mil from PDB,

TABLE 6

Oxygen and Carbon Isotope Data for Globigerinoides obliquus at DSDP Site $134($ Leg 13)

\begin{tabular}{ccrr}
\hline $\begin{array}{c}\text { Sample } \\
\text { (Interval in cm) }\end{array}$ & Species & $\delta 18 \mathrm{O}$ & ${ }^{13}{ }^{13} \mathrm{C}$ \\
\hline $7-4,2$ & Globigerinoides obliquus & 0.0 & +1.6 \\
$7-5,11$ & Globigerinoides obliquus & -0.5 & +1.1 \\
$7-5,70$ & Globigerinoides obliquus & +0.2 & +1.7 \\
$7-5,124$ & Globigerinoides obliquus & -0.4 & +1.7 \\
\hline
\end{tabular}

aExpressed as deviation per mil from PDB.

as a salinity curve. After a sharp increase of the $\delta^{18} \mathrm{O}$ values from an average of $+0.74 \%$ in the Langhian section to a maximal value of $+2.15 \%$ in the lower Serravallian (Core 18), the $\delta^{18} \mathrm{O}$ then oscillates around an average value of $+1.63 \%$ in the upper Serravallian and lower Tortonian. The maximal values which are reached in the upper Serravallian, around

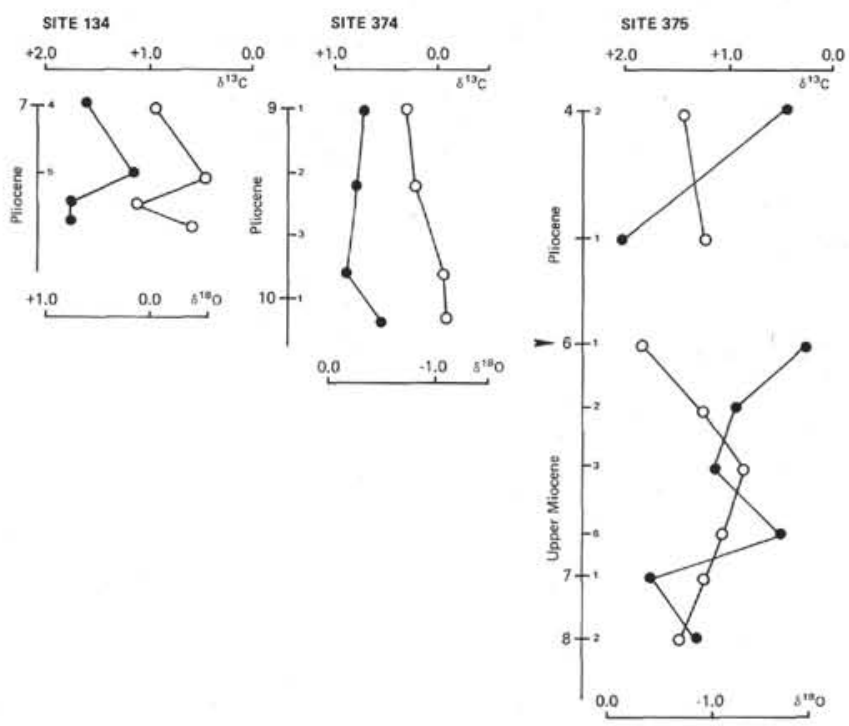

Figure 3. Oxygen and carbon isotopic composition of Globigerinoides obliquus from the G. margaritae Zone and of other species from Sites 374, 375, and 134. Open circles: $\delta^{180}$; dark circles: $\delta^{13} \mathrm{C}$. 
$+2.7 \%$, are in fact higher than the values that are registered today by the species which deposit their shells in isotopic equilibrium. Since we are dealing here with mixed species, the resulting mean isotopic composition that we are measuring, may well be lower (because of the non-equilibrium deposition of some shells) than the true isotopic value; in other words, these very high $\delta$ values should be considered as minimal values.

Because we do not have evidence of bottom cooling from the Langhian to early Serravallian time, the successive increases in the $\delta^{18} \mathrm{O}$ of the benthic shells probably reflect the production of isotopically enriched, high saline waters, the average increase of the $\delta_{\text {water }}$ being:

$$
1.63-0.74=0.89 \% \text { 。 }
$$

If one accepts the minimal estimate of $-0.9 \%$ 。 for early Miocene bottom waters one can calculate a minimal value around $0 \%$ (on the PDB scale) for the bottom waters of the middle Miocene. This increase corresponds to the isotopic evolution of mean oceanic waters, according to the evaluations made by Shackleton and Kennett, (1975a, b), which are attributed to the building of the Antarctic ice cap, starting at about -12 m.y.B.P.

Nevertheless, even if this average increase of $0.9 \%$ 。 in the isotopic composition of Mediterranean waters reflects the mondial evolution of oceanic waters, the secondary and rapid oscillations towards high $\delta$ values in the middle and late Serravallian strongly suggest an evolution peculiar to the Mediterranean Sea, which could be interpreted as minor salinity crises preceding the "Messinian salinity crisis."

\section{Surface Waters}

The oxygen isotopic composition of planktonic foraminifera increases from an average value of $-1.18 \%$ (during the Langhian) to an average value of $-0.98 \%$ (in the Serravallian and lower Tortonian), that is to say an increase of $0.2 \%$ Assuming that the whole water column was affected by a minimal $\delta$ increase of $0.9 \%$ o this means that a temperature effect of at least $0.7 \%$ o lowered the mean isotopic composition of planktonic foraminifera. Thus we calculate that the surface temperatures increased by a minimal value of $3^{\circ} \mathrm{C}$.

\section{Tortonian or Messinian? Increasing Salinities}

In Site 372, Core 29, Section 2, which is near the $G$. acostaensis Zone (cf. Bizon, this volume), a strong shift towards high $\delta^{18} \mathrm{O}$ positive values in planktonic foraminifera occurs (we do not have any benthic foraminifera from the same levels); this shift is accompanied by a corresponding one in the $\delta^{13} \mathrm{C}$ values towards a positive value. Because the microfauna gives no evidence of cooling, this may be interpreted as a strong variation in the $\delta^{18} \mathrm{O}$ of the sea, probably in the whole water column, and may be correlated with an increasing salinity (reflected itself in the disappearance of Orbulina universa at that precise level, Core 9, Section $2,110 \mathrm{~cm}$ ).

We have also recorded the $\delta^{18} \mathrm{O}$ measured on preMessinian foraminifera from a nearby locality (Core FP69, collected by Mauffret; see Bizon et al., 1975). The analyses were carried out on Globorotalia mediterranea and Globigerinoides trilobus. The values obtained are:

$$
\begin{array}{ll}
\text { G. trilobus } & \delta^{18} \mathrm{O}=+1.84 \\
& \delta^{13} \mathrm{C}=+0.13 \\
\text { G. mediterranea } & \delta^{18} \mathrm{O}=+2.11 \\
& \delta^{13} \mathrm{C}=-0.70
\end{array}
$$

Thus, in upper Miocene time there were repeated shifts in the oxygen isotopic composition of planktonic foraminifera, from first, an average value of $-1.0 \%$ to values of $+0.8 \%$ (level $9-2,110 \mathrm{~cm}$ ), to second, $+2.0 \%$, resulting in a global increase of $+3.0 \%$ 。 Since the fauna analyzed at FP69 seem rather warmer than those of Core 9, Section $1,125 \mathrm{~cm}$, at Site 372 , one might assume that the variations which have been registered correspond to a marked variation in the isotopic composition of the sea. Although this variation might be the result of glacial effects from the Antarctic ice sheet, most probably, since it involves planktonic foraminifera as well, it reflects increased evaporation during the Messinian salinity crisis.

\section{Carbon Isotope Data}

At the present state of our knowledge, little information can be drawn from the variations of the carbon isotope ratio. We know that today, and probably also during the Pleistocene, the variations of the $\delta^{13} \mathrm{C}$ of the total dissolved carbon relative to depth, in the Mediterranean, were very small (from $+1.5 \%$ o to $+1.2 \%$ in the upper $100 \mathrm{~m}$ ); at decper levels, the content remains constant. As a consequence, the difference between the measured values

$$
{ }^{13} \mathrm{C}_{\text {plankton }}-\delta^{13} \mathrm{C}_{\text {benthic }}
$$

is small and even may be negative, due to the nonequilibrium precipitation in foraminifera.

What we can observe in the Miocene section here, is that the difference $\delta^{13} \mathrm{C}_{\text {plankton }}-\delta^{13} \mathrm{C}_{\text {benthic }}$ is relatively high (from $+1.2 \%$ in the lower Miocene to $+1.8 \%$ 。 in the middle Miocene). This implies that the $\delta^{13} \mathrm{C}$ profiles of total dissolved carbonate in the Mediterranean were significantly different at that time, and much closer to those of the open ocean. Even if the conditions were no longer that of a totally open basin, the hydrologic circulation and removal of the waters was not identical to the present system. As the Messinian salinity crisis approached (Core 2, Section 9) the average $\delta^{13} \mathrm{C}$ value became negative as a result of the episodic influences of diluted waters (from continental origin or other).

In conclusion, since Langhian time at least, the Mediterreanen Sea was dissimilar to the open ocean 
with a minimal $\delta_{\text {water }}$ value of $-0.9 \%$ and the $\delta_{\text {water }}$ evolved through the Serravallian and Tortonian times, increasing on the average of $0.9 \%$. This average increase could well reflect the Antarctic ice build-up as suggested by Shackleton and Kennett (1975a, b), but it also could reflect minor salinity crises producing high density and isotopically enriched bottom waters. These minor crises prepared the way for the major salinity crisis of the Messinian which is clearly reflected in the sharp oscillations in the $\delta^{18} \mathrm{O}$ recorded in Core 9, Section 2, while the $\delta^{13} \mathrm{C}$ values of the same period implicate episodic continental contaminations.

\section{Site 374}

The analyses were made on Globigerinoides obliquus from the Globorotalia margaritae Zone; the oxygen isotopic composition is similar to that of the upper Miocene fauna from Site 372.

\section{Site 375}

The few data obtained for the Pliocene series suggest conditions similar to that of Site 374. The comparison of the results obtained for Sites 374 and 375 and Site 134 (DSDP Leg 13), for Globigerinoides obliquus from the same Globorotalia margaritae Zone in the lower Pliocene, shows that there exists a difference of about $1 \%$ in the isotopic composition of oxygen registered in the western and eastern Mediterranean basins. If this difference is to be attributed to a different isotopic composition of the seawater, it means that, during the lower Pliocene, the marine conditions were exactly the opposite of what they are today; the eastern Mediterranean basin was more diluted as a consequence or an "after effect" of its "Lago-mare" condition during the late Miocene.

\section{ACKNOWLEDGMENTS}

The author expresses her thanks to G. Bizon, M. B. Cita, R. Létolle, and N. J. Shackleton who critically reviewed the manuscript; and particularly for the helpful suggestions made by the latter reviewer. Discussions with $\mathrm{F}$. Mélières and $\mathrm{A}$. Mauffret were most stimulating. She expresses a special acknowledgment to G. Bizon for providing complementary samples at all sites. Thanks are also extended to Mrs. Dudouyt for laboratory assistance.

\section{REFERENCES}

Benson, R. H. 1972. Ostracodes as indicators of threshold depth in the Mediterranean during the Pliocene. In Stanley, D. J. (Ed), The Mediterranean Sea, Stroudsburg, Pa., (Dowden, Hutchinson and Ross), p. 63-73.

, Psychrospheric and continental Ostracoda from ancient sediments in the floor of the Mediterranean. In Ryan, W. B. F., Hsü, K. J. et al., Initial Reports of the
Deep Sea Drilling Project, Volume 13: Washington (U.S. Government Printing Office), p. 1002-1008.

Benson, R. H. 1974. An Ostracodal view of the Messinian salinity crisis. In Drooger, C. W., (Ed.), Messinian Events in the Mediterranean, Utrecht 1973: Amsterdam, '(NorthHolland Publ. Co.), p. 235-242.

Benson, R. H. and Ruggieri, C., 1974. The end of the Miocene, the time of crisis in the Tethys, Mediterranean history. In 75th Anniv. Egypt. Geol. Surv. Proc., Cairo 1971, Symp. Afric. Paleontol. Spec. Bull.

Benson, R. H. and Sylvester-Bradley, P. C., 1971. Deep-sea Ostracodes and the transformation of ocean to sea in the Tethys: SNPA, Bull., Pau, 5 Suppl., p. 63-91.

Bizon, G., Bizon, J.-J., and Mauffret, A., 1975. Présence de Miocène terminal et de Pliocene inférieur au large de Minorque (Baléares, Espagne): Rev. Inst. Franç. Pétrole, v. 30 , p. 713-727.

Craig, H., 1965. The measurements of oxygen isotope paleotemperatures In Stable isotopes in oceanographic studies and paleotemperatures; Spoleto 1965, CNR Pisa, p. 161182.

Devereux, I., 1967. Oxygen isotope paleotemperature measurements on New Zealand Tertiary fossils: New Zealand J. Sci., v. 10, p. 988-1011.

Douglas, R. G. and Savin, S. M. 1971. Isotopic analyses of planktonic foraminifera from the Cenozoic of the Northwest Pacific, Leg 6. In Fischer, A. C., Heezen, B. C., et al., Initial Reports of the Deep Sea Drilling Project, Volume 6: Washington (U.S. Government Printing Office), p. 1123-1127.

Douglas, R. G. and Savin, S. M. 1973. Oxygen and carbon isotope analyses of Cretaceous and Tertiary foraminifera from the central north Pacific. In Winterer, E. L., Ewing, J. I., et al., Initial Reports of the Deep Sea Drilling Project, Volume 17: Washington, (U.S. Government Printing Office), p. 591-605.

Duplessy, J. C., 1972. La geochimie des isotopes stables du carbone dans la mer: Doctoral thesis, Paris, France.

Emiliani, C., 1955. Pleistocene Temperatures: J. Geol., v. 63 , p. $538-578$.

Lacombe, H. and Tchernia, P., 1971-1972. Le problème de la formation des eaux marines profondes. Déroulement du phénomène en Méditerranée Nord-Occidentale par hiver très froid (Janvier-Mars 1963): Ann. Inst. Océanogr., XLVIII, p. 1-112.

Shackleton, N. J. and Kennett, J. P. 1975a. Late cenozoic oxygen and carbon isotopic changes at DSDP Site 284: implications for glacial history of the northern hemisphere and Antarctica. In Kennett, J. P., Houtz R. E., et al., Initial Reports of the Deep Sea Drilling Project, Volume 29: Washington (U.S. Government Printing Office), p. 801-807.

, 1975b. Paleotemperature history of the Cenozoic and the initiation of antarctic glaciation: oxygen and carbon isotope analyses in DSDP sites 277, 279 and 281 In Kennett, J. P., Houtz, R. E., et al., Initial Reports of the Deep-Sea Drilling Project, Volume 29: Washington (U.S. Government Printing Office), p. 743-755.

Vergnaud Grazzini, C., 1973. Etude écologique et isotopique de Foraminifères actuels et fossiles de Méditerranée: Doctoral Thesis, Paris, France. 